\title{
Water and Ice-Related Phenomena in the Coastal Region of the Beaufort Sea: Some Parallels between Native Experience and Western Science
}

\author{
EDDY CARMACK ${ }^{1,2}$ and ROBIE MACDONALD ${ }^{2}$
}

\author{
(Received 19 July 2007; accepted in revised form 26 November 2007)
}

\begin{abstract}
Information gained through Native experience is combined here with scientific measurements to describe aspects of the wintertime oceanography of the Eskimo Lakes and Mackenzie River delta regions of the Canadian Beaufort Sea. The experiences of Jimmy Jacobson, a Tuktoyaktuk elder who lived in this region for over 70 years, were used as the basis for scientific planning and measurement. We focus on phenomena of special relevance to winter travel and fishing in four specific examples of Native insight guiding scientific inquiry. First, we examine local knowledge of ice characteristics and fish abundance in terms of tidal dispersion and its effect on mixing patterns during winter. Second, we relate the maintenance of a small ice-free area, used by caribou as a salt lick, to the vertical heat flux associated with flow through narrow channels. Third, we look at potentially dangerous episodes of overflooding of snow and ice in the nearshore zone in midwinter, caused by strong westerly winds, through the analysis of oxygen isotope distributions in ice cores. Fourth, we discuss the important influence of wind direction on ice conditions, lead formation, and brine production in semi-enclosed coastal bays. Finally, we note certain circulation features of ecological significance relevant to concerns about development and the transport of pollutants. We conclude that by not requiring agreement between indigenous knowledge and Western science, or ranking one above the other, we can realize the values of each approach. Specifically, indigenous knowledge can provide direction to scientific inquiry, while Western science can be used to measure, model, and predict where development or change might have the most serious impact.
\end{abstract}

Key words: Arctic oceanography, Beaufort Shelf, indigenous knowledge, Jimmy Jacobson, northern ecosystems

RÉSUMÉ. L'information acquise grâce à l'expérience des Autochtones est jumelée ici aux mesures scientifiques afin de donner lieu à la description des aspects de l'océanographie hivernale des régions des lacs Eskimo et du delta du fleuve Mackenzie dans la mer canadienne de Beaufort. L'expérience de Jimmy Jacobson, un ancien de Tuktoyaktuk qui habite dans la région depuis plus de 70 ans, a servi de fondement à la planification et aux mesures scientifiques. Nous nous concentrons sur les phénomènes qui revêtent une importance particulière dans le cadre des déplacements et de la pêche d'hiver de quatre exemples particuliers visant les perspectives autochtones ayant guidé l'enquête scientifique. Premièrement, nous examinons les connaissances locales pour ce qui est des caractéristiques propres à la glace et à l'abondance des poissons en termes de dispersion tidale et des effets sur les modèles de brassage pendant l'hiver. Deuxièmement, nous établissons un rapport entre le maintien de petites zones sans glace, dont les caribous se servent en guise de vasière, et le flux thermique vertical associé aux coureaux d'écoulement. Troisièmement, nous nous penchons sus des épisodes potentiellement dangereux de surinondation de neige et de glace dans la zone côtière en plein milieu de l'hiver, ce qui serait causé par de forts vents de l'ouest, en nous fondant sur l'analyse de la répartition des isotopes d'oxygène dans les carottes glaciaires. Quatrièmement, nous discutons de l'importante influence de l'orientation du vent sur le régime des glaces, la formation de filons et la production de saumure dans les baies côtières partiellement enfermées. En dernier lieu, nous faisons mention de certaines caractéristiques de circulation revêtant une importance écologique vis-à-vis des inquiétudes en matière de formation et de transport des polluants. Nous en concluons qu'en ne recherchant pas d'entente entre les connaissances des Autochtones et la science occidentale, ou qu'en accordant une préséance à l'une ou l'autre de ces notions, nous pouvons réaliser les valeurs de chaque approche. Plus précisément, les connaissances indigènes peuvent guider l'enquête scientifique, tandis que la science occidentale peut servir à mesurer, modéliser et prédire là où le développement ou le changement est susceptible d'avoir de plus grandes incidences.

Mots clés : océanographie de l'Arctique, plateau de Beaufort, connaissances indigènes, Jimmy Jacobson, écosystèmes du Nord

Traduit pour la revue Arctic par Nicole Giguère.

\footnotetext{
${ }^{1}$ Fisheries and Oceans Canada, Institute of Ocean Sciences, P.O. Box 6000, Sidney, British Columbia V8L 4B2, Canada

${ }^{2}$ Corresponding author: CarmackE@pac.dfo-mpo.gc.ca

(C) The Arctic Institute of North America
} 


\section{INTRODUCTION}

It is widely recognized that valuable information about natural systems resides in the experience and understanding of Native peoples (see Huntington and Fox, 2005 for a comprehensive overview). A challenge, however, lies in the meaningful and appropriate transfer of such information to environmental scientists. In fact, there is little agreement even on the use of appropriate terms to describe the experiential knowledge of indigenous people (see Colorado, 1986; Johannes, 1989; and Turner et al., 2000; for examples of diverse application). Following Huntington and Fox (2005), we use here the term "indigenous knowledge" to encompass various systems of knowledge, practice, and belief. Likewise we use the inadequate term "Western science" to delimit investigation based on classical scientific methods such as induction, deduction, hypothesis testing, and modeling (cf. Popper, 1983). As Arctic marine (e.g., Western) scientists ourselves, however, we have not found any compelling examples in which indigenous knowledge has been directly applied in either field studies or modeling of biogeochemical processes. Even the most recent synthesis, the Arctic Climate Impact Assessment (ACIA, 2005), keeps separate topical chapters on indigenous knowledge and ecological systems. Similarly, the many excellent compilations of indigenous observations relating to a changing climate (McDonald et al., 1997; Riedlinger and Berkes, 2001; Krupnik and Jolly, 2002) do not bridge the gap between indigenous knowledge and Western science. It is not our intention here to criticize previous efforts to document the value of indigenous knowledge, but rather to emphasize how difficult it is to bring this knowledge to bear on topics like oceanography. As a modest start, we offer examples of how this might be accomplished based on our extended conversations with a Native elder and personal experiences gained while conducting interdisciplinary field studies in the coastal Beaufort Sea.

We explore here a type of "co-science" in which natural phenomena are examined through both indigenous and Western methods; each approach is assumed valid within its own set of rules, and neither replaces the other. If we accept a definition of a scientist as someone who uses observation, experimentation, and theory to learn about a subject, then the term "scientist" can be applied to an elder: here observation becomes experience; experimentation becomes replication, or what works for survival and what doesn't work; and theory becomes the legends and teaching stories passed from generation to generation. Indeed, the success of traditional knowledge over millennia of climate change is founded on experimentation, innovation, and adaptation. For a given natural phenomenon, for example, the "indigenous scientist" will know its signals, visible signs, and value to survival, while the Western scientist will know analytical methods to measure and model it. In applying both methods, we attempt to find inherent value and common links; we must accept the

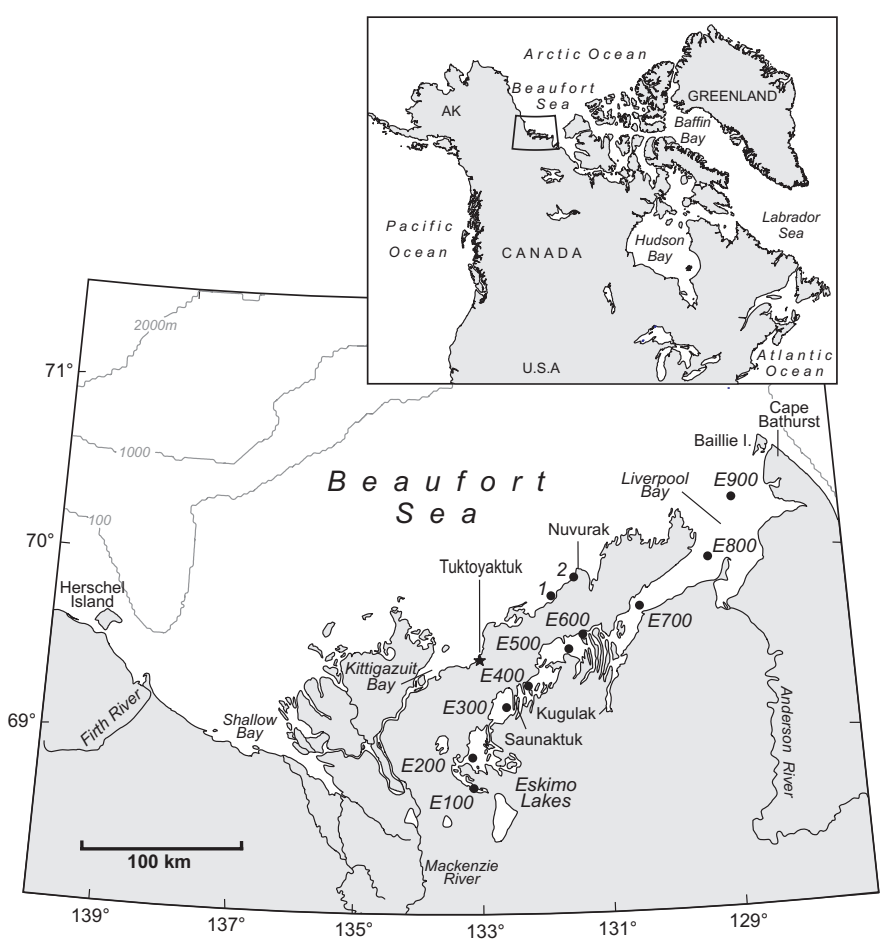

FIG. 1. Maps showing the study area and sites discussed in the text; greater detail is given in Figure 2.

differing assumptions and goals of indigenous knowledge and Western science. The practical and emergent outcome of this approach is that joint inquiry will focus on phenomena that are important to Native peoples for their way of life and will bring Western scientists closer to a "systems science" level of understanding with the potential of providing outcomes useful for both Western science and for Native people facing adaptation to rapid social and ecological change.

This paper reports our attempt to use Native observations of nature to influence the design and focus of field and modeling studies aimed, ultimately, at understanding processes that may influence the dispersion and consequences of hydrocarbons introduced as a result of offshore oil and gas development. Our examples are drawn from the region of the Mackenzie Delta and the Eskimo Lakes, where we have intermittently carried out seasonal research since 1986, and where Jimmy Jacobson (1921-94), our source of indigenous knowledge, lived, hunted, and fished year-round for over 70 years.

\section{BACKGROUND}

\section{Study Area}

The study region is bounded on the west by Herschel Island, on the east by Baillie Island, and on the north by the coastal Beaufort Shelf, and it includes the Eskimo Lakes to the south (Fig. 1; and see Mackay (1963) and Brunskill (1986) for regional overviews). Two estuaries lie within 
this domain. The first is formed by the Mackenzie River, the 12th largest river in the world, which delivers $330 \mathrm{~km}^{3}$ of water and $124 \times 10^{6}$ tonnes of sediment each year to the Beaufort Shelf (Macdonald et al., 1998). Because of its large freshwater discharge, the estuary itself is formed by the river plume extending offshore onto the continental shelf to approximately the $20 \mathrm{~m}$ isobath (Carmack et al., 1989; Macdonald and Carmack, 1991).

The second estuary is the $300 \mathrm{~km}$ long system consisting of the Eskimo Lakes and Liverpool Bay (Fig. 1); for scale comparison, we note that this system is about equal in length and area to Chesapeake Bay. The relatively flatbottomed Liverpool Bay has a mean depth of about $12 \mathrm{~m}$ and a surface area of about $4600 \mathrm{~km}^{2}$. It is separated from the Eskimo Lakes near Kugulak by a shallow sill approximately $4 \mathrm{~m}$ deep. The Eskimo Lakes, with a total surface area of $17000 \mathrm{~km}^{2}$, are partitioned into four sub-basins by groups of long, bowed peninsulas or "fingers" extending north and south into the lake. Within the Eskimo Lakes, the bottom profile is formed by an extremely complex series of shallow sills and deep basins, which appear to be subsurface expressions of the fingers. Several holes exceed $50 \mathrm{~m}$ in depth, the deepest approaching $100 \mathrm{~m}$ (Fig. 2). The total catchment for Liverpool Bay and the Eskimo Lakes is $98000 \mathrm{~km}^{2}$, of which about $90 \%$ drains into Liverpool Bay. Annual freshwater discharge into the Eskimo Lakes is about $1 \mathrm{~km}^{3} \mathrm{yr}^{-1}$, and for Liverpool Bay, it is $10 \mathrm{~km}^{3} \mathrm{yr}^{-1}$ (Gushue et al., 1996). The amount of freshwater supplied by ice melt to the Eskimo Lakes (about $2 \mathrm{~m}$ averaged over the surface area) is greater than that supplied by runoff and precipitation (about $0.5 \mathrm{~m}$ ), and both inputs are delivered to the system in early summer (Macdonald et al., 1999). Despite the importance of the Eskimo Lakes as a source of country foods, little recent work has been done there: oceanographic conditions in the Eskimo Lakes during summer were described by Grainger and Evans (1982), the climatology was summarized by Mackay (1963), and the region was recently reviewed for inclusion in a Large Ocean Management Area (LOMA: Fisheries and Oceans Canada, 2007).

Traditional place names often have significance, reflecting a keen awareness of local geography and ecology (Basso, 1996; Rayburn, 2001; Kari and Fall, 2003). For example, Jimmy Jacobson told us that the name "Tuktoyaktuk," which replaced the Western name "Port Brabant" in 1950, comes from a story of a medicine man. Angered by two caribou that had escaped from him by swimming across the bay, he turned them into stones. Today, these two stones mark the entrance to Tuktoyaktuk harbor at low tide. The indigenous name for the Eskimo Lakes is Emargleeook, which roughly means 'lake after lake with no end of water' and aptly describes the vastness of this complex, interconnected system. The long, fingerlike channels of the lake are called Sheeneek, 'many fingers.' The small inlet at the southwest end of Liverpool Bay is called Kugulak, 'place at the end of the inlet,' and is the place where three different water types mix to form a highly productive estuary. Nicholson Island, located in Liverpool Bay immediately north of the Anderson River (Fig. 1), is called Nihakrok, 'shape of a man's head,' after a prominent pingo on the southwestern tip of the island. Stanton, a small bay on the south side of Liverpool Bay, is called Kikalaywook, 'may be good fishing.' The important point here is not to provide a definitive list of indigenous place names, but simply to note that such names still carry significant local knowledge. These names are analogous to specialized terms of Western science, in that they are used to communicate technical information to an audience (Morrow and Schneider, 1995).

\section{Development Concerns}

The research was initiated as part of the Northern Oil and Gas Action Program (NOGAP). This federal program was designed to advance the state of federal and territorial government preparedness for major hydrocarbon development north of $60^{\circ}$, with preparedness defined as acquiring the knowledge and analytical capability to make appropriate decisions concerning industrial development proposals. At the same time, people who live in the North have especially strong concern that development might disrupt their way of life. Given that environmental concerns for hydrocarbon development remain as strong as ever, and that climate change will likely promote other forms of development (e.g., transport, tourism, fisheries), it is critical that all forms of knowledge and best practices be brought to bear on the making and setting of policy to manage resources (Berger, 1985; Usher, 2000).

\section{METHODS}

Following initial studies of the Beaufort Shelf between 1986 and 1988, our research entered a second phase in 1991, in which we narrowed the focus to nearshore processes of greater relevance to local communities. Working from skidoos and temporary field camps, we required a local guide. Recommendations led us quickly to Jimmy Jacobson, an elder of Tuktoyaktuk who had developed a reputation for guiding during earlier oil exploration activities of the 1970s. Jimmy had retired from such activities, but suggested that with his tutoring, his grandson (and adopted son) Jackie could meet our needs in the field. It was during this planning and tutorage, which occurred informally as we met over coffee with Jimmy and his grandson Jackie, that we saw the need to revise and refocus our science plan from one based on traditional biogeochemical sections to one that addressed emerging topics and places that appeared to be of critical importance to regional ecosystems.

\section{Traditional Knowledge}

Indigenous people living in this region have acquired skills that allow them to travel safely and acquire food. 

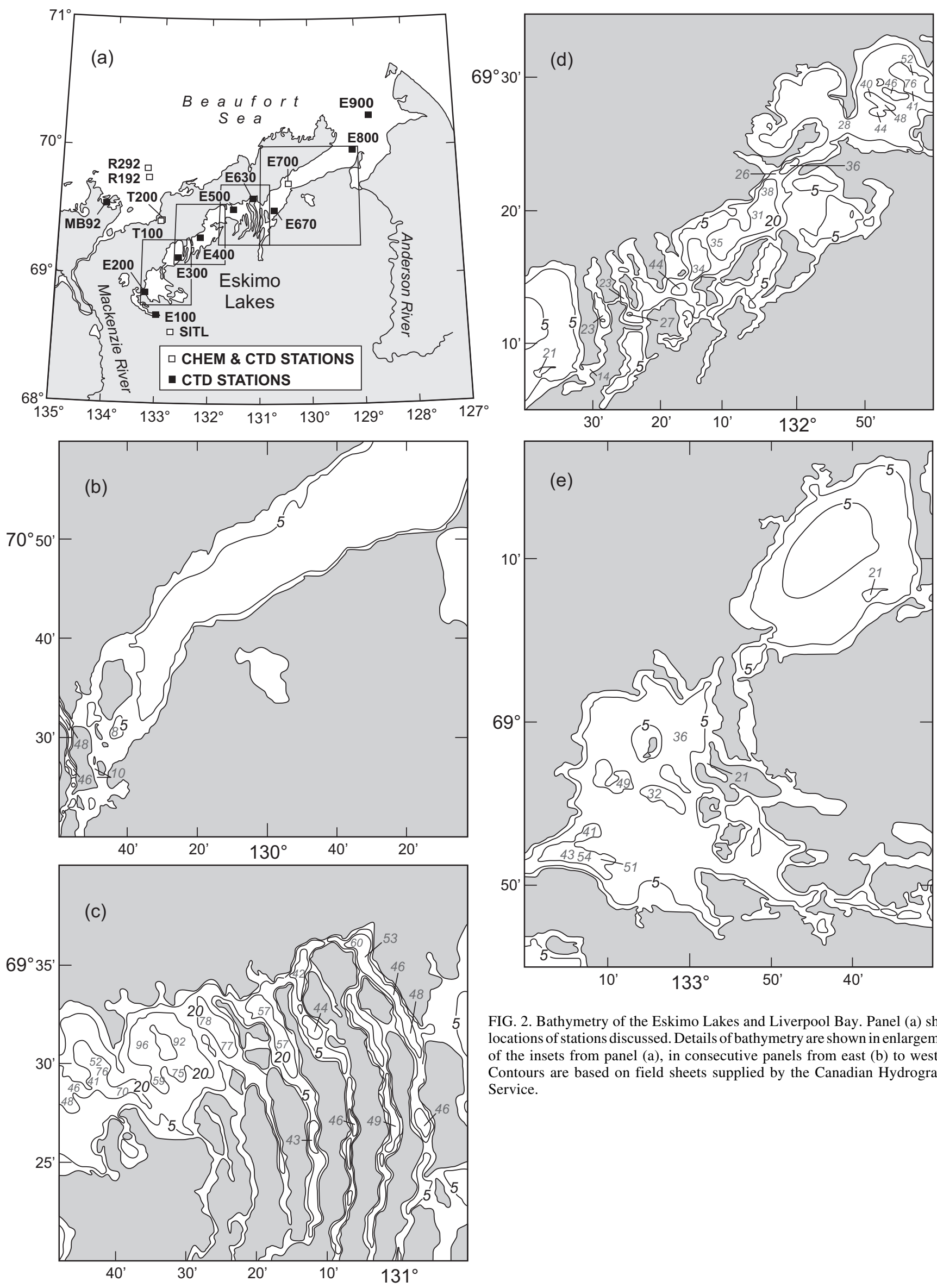

FIG. 2. Bathymetry of the Eskimo Lakes and Liverpool Bay. Panel (a) shows locations of stations discussed. Details of bathymetry are shown in enlargements of the insets from panel (a), in consecutive panels from east (b) to west (e). Contours are based on field sheets supplied by the Canadian Hydrographic Service. 
These skills are attained through experience in travel across mixes of land and water that seasonally freeze and thaw: landscapes that provide little in the way of landforms by which to navigate. According to Jimmy Jacobson, "When an Eskimo sees a piece of land, he doesn't forget it, because he might need it later to survive." This detailed knowledge of landforms underscores the traditional ability to recognize and recall details of natural phenomena. Each season brings with it a different requirement for travel and for gathering food. During winter, the frozen landscape makes it possible to move out onto the land and sea to trap, fish, and hunt. In late winter and spring, it is easy to get across Tuktoyaktuk peninsula to the Eskimo Lakes by sled and to collect trout, geese, and caribou. After breakup, coastal fishing and whaling become important.

The observational methods used by Jimmy Jacobson were based on his experience and knowledge developed while living on the land. It follows that his biographical sketch, obtained during conversations, portrays best the descriptive power of his indigenous knowledge and scientific method.

Jimmy Jacobson was born in 1921 on Baillie Island. His mother, Vera Kigyun, was an Inuvialuit from Kittigazuit near the mouth of the Mackenzie River. His father, Fred Jacobson, was a Russian sailor whose ship was beset in ice, and who subsequently went to live among the Inuvialuit on Baillie Island. Jimmy was adopted by his mother's sister and her husband, who had no sons. Jimmy's adoptive parents took him with them to live at Herschel Island, where he was exposed early to fishing and whaling. When Jimmy was seven, an influenza epidemic brought by white traders killed his adopted parents, along with most of the other adults on Herschel Island. He recalls waking up one morning lying between his adopted mother and father, and realizing that both were dead.

Jimmy was then sent to school in Hay River on Great Slave Lake for five years. Instead of attending classes and learning to read and write English, Jimmy was required to work for the school gathering and cutting wood. At age 12, he returned to the Mackenzie Delta area to rejoin the family of his natural parents. He spent the next few years in and around Liverpool Bay and Cape Bathurst, where he learned to hunt, trap, and fish, and to travel by boat and dogsled, by carefully "watching the old-timers." At age 15 , possessing only a parka, Jimmy left home, taking on jobs such as wood-cutting in exchange for traps and other supplies he would later need to live off the land.

Jimmy married Bella in 1940. Bella's father, Frank William, was a white miner and trapper who came to the region from the Yukon after spending time in the Klondike. Her mother, Germaine, was a Dene from Fort Good Hope on the middle course of the Mackenzie River. Bella's father drowned while prospecting shortly after her birth. The river in which he drowned was subsequently referred to as the "Miner" River. Bella was known as the "best dogteam racer" when she and Jimmy were married. Her strength and traditional skills allowed her to accompany Jimmy in extensive travels in both summer and winter, while at the same time raising a family of ten children.

Throughout most of his life, Jimmy's main sources of income were fur trading and fishing. However, when the oil boom came in the early 1970s, Jimmy adapted to new opportunities first by serving as a guide to exploration teams, and later by forming his own company to provide guide and bear-monitoring services to the oil industry. It was through the need of the NOGAP field team for bearmonitoring services that the authors met Jimmy and his grandson Jackie, who subsequently joined in the fieldwork as guide and technical assistant. Jimmy Jacobson passed away in Tuktoyaktuk in 1994.

\section{Western Science}

Fieldwork was carried out from the Polar Continental Shelf Base in Tuktoyaktuk using helicopters, fixed-wing aircraft, and sleds pulled by skidoo. The locations of sampling stations, ice cores, and current meter moorings are shown in Figure 1. Measurements and water samples were obtained by first drilling 8 to 12 inch holes in the ice using power augers.

Temperature (T) and salinity (S) were measured using Seabird SBE19 self-contained Conductivity-TemperatureDepth (CTD) recorders; accuracies were determined to be $\mathrm{T}= \pm 0.01^{\circ} \mathrm{C}$ and $\mathrm{S}= \pm 0.02$. Currents were measured at two mooring locations, one in Liverpool Bay and one in the Eskimo Lakes, with two internally recording Aanderaa (Savonius rotor type) current meters (velocity uncertainty $\pm 0.02 \mathrm{~ms}^{-1}$; direction uncertainty $\pm 10^{\circ}$ ) at each mooring. An internally recording tide gauge was also deployed at each site. A $600 \mathrm{kHz}$ Acoustic Doppler Current Profiler made by RDI $\left(\mathrm{V}= \pm 0.01 \mathrm{~ms}^{-1} ; \mathrm{D}=5^{\circ}\right)$ was deployed at the Eskimo Lakes mooring.

Water-column chemistry included dissolved oxygen, silicate, phosphate, nitrate, stable oxygen isotopes $\left(\delta^{18} \mathrm{O}\right)$, chlorofluorocarbon 11 and 12, total suspended solids, and selected hydrocarbons. Ice cores were taken at each sampling site using a Sipre corer, then sectioned and analyzed for salinity and oxygen isotope composition $\left(\delta^{18} \mathrm{O}\right.$; for the mathematical formulation, see Macdonald and Carmack, 1991). Organochlorine content was measured in water samples, bottom sediments, amphipods, and fish. Not all measurements arising from the work influenced by Jacobson are reported here; detailed descriptions of methods are given in Macdonald et al. (1992) and Pearson et al. (1994).

\section{CIRCULATION AND MIXING IN THE ESKIMO LAKES}

\section{Setting and Narrative}

Our first discussion concerns the large-scale wintertime oceanography of the Eskimo Lakes. That this complex system of deep basins, shallow sills, and long finger-like channels is, in fact, a strongly mixed estuary was first 
made known to us in talks with Jimmy Jacobson in April 1991. He recalled how "in the old days" he did not like to cross the mid-portion of the lake by dog sled in the early freeze-up period because "my dogs' feet would stick to the ice" making passage difficult. Jimmy also told of a time he and Bella were returning from trapping in the Kugulak region immediately after freeze-up, and the ice was so thin that "it started to bend like rubber under the weight of the sled, so we turned back fast!" Now, these qualities of stickiness and flexibility are characteristic of ice formed from relatively salty water, not from the fresh water we had assumed for the middle reaches of the lake. We were impressed by the apparent strength of the estuarine circulation, seemingly capable of transporting large amounts of salty water upstream from Liverpool Bay over shallow sills (minimum depth of 2 to $4 \mathrm{~m}$ ) and through winding, narrow passages. This suggested to us that the Eskimo Lakes could, in fact, be affected by offshore oil or contaminant spills transported into Liverpool Bay and then carried "upstream" into the lakes.

\section{Observations and Analysis}

Because of Jimmy's observations, we added a preliminary survey of temperature and salinity in the Eskimo Lakes to the 1991 field program and, indeed, we found saline surface water along almost the entire length of the system. Inspired by these results, we designed the spring 1992 field program around Jimmy's accounts. The following discussions are based on the results of that work.

Figure $3 \mathrm{a}$ shows the section of salinity (reported in practical salinity units) along the $300 \mathrm{~km}$ long centerline of the estuary, with an overview at the top showing locations referred to in Jimmy's narratives described below. The section has not been corrected for tidal excursions, which are typically less than $0.5 \mathrm{~m}$. Saline water extends the full length of the system, showing that the suite of shallow and narrow sills along the axis do not block the estuarine circulation. At any given location, the water column remains weakly two-layered, with variation from basin to basin in the strength and depth of the halocline, although for all basins the isolines of salinity are strongly inclined to the vertical, with large horizontal gradients, suggesting that intense tidal mixing occurs. This inclined salinity (density) structure is in direct contrast to the under-ice structure observed offshore in the Mackenzie Estuary (Macdonald et al., 1999), where isolines of salinity are virtually horizontal despite the proximity to ocean forcing.

Water temperature is of paramount importance when considering the formation of ice, since ice can form only when water is at its freezing temperature, $\mathrm{T}_{\mathrm{f}}$, for a given salinity, $\mathrm{S}$, where $\mathrm{T}_{\mathrm{f}}=\sim-0.014-0.052 \mathrm{~S}$ (Lewis and Perkin, 1983), and where heat is being removed from the system. Conversely, the potential for heat in the water column to melt ice is related directly to the temperature of the water above freezing, $\Delta \mathrm{T}_{\mathrm{a}}=\mathrm{T}-\mathrm{T}_{\mathrm{f}}$, and to the opportunity for such water to come in contact with the ice.
Figure $3 b$ shows a section of $\Delta \mathrm{T}_{\mathrm{a}}$ along the estuary. Water temperatures above freezing are found immediately below the near-surface mixed layer along the entire length of the estuary, implying that heat is trapped by the estuarine (layered) stratification at the time of freeze-up, and not all of this heat is removed by mixing upwards to the base of the ice cover during the course of the winter. For estuarine waters undergoing freezing, the 24.7 salinity has unique significance. Brackish water with salinity below 24.7 has a temperature of maximum density above its freezing temperature. As this water is cooled below its temperature of maximum density, it becomes lighter. In contrast, water of salinity above 24.7 always becomes heavier as it is cooled toward the freezing point. This means that there are two potential ways for stratification to trap heat: by salinity stratification at salinities above 24.7 and by temperature stratification at salinities below 24.7. In the Eskimo Lakes system, salinity stratification tends to trap heat at depth in the lower layer, while temperature stratification tends to trap additional heat at the base of the upper mixedlayer.

A typical characteristic of deep, fjord-like basins with shallow sills is that the deeper waters are isolated, with slow flushing rates and low dissolved-oxygen concentrations. The Eskimo Lakes do not exhibit this typical characteristic: dissolved oxygen shows uniform high concentrations at all depths (Fig. 4), indicating either that ventilation is strong or that productivity is weak, or both (see, e.g., Grainger and Evans, 1982). With regard to impacts from oil or other contaminants, the Eskimo Lakes exhibit a more immediate connection with the ocean; for example, the chemical dispersion of oil in Liverpool Bay would likely lead to its entry into the deeper waters of the Eskimo Lakes.

Figure 5, a two-week time series of bottom pressure (representing water level) for moorings in both Liverpool Bay (E800) and the Eskimo Lakes (E600), and Figure 6, the corresponding velocity records, show that the flow field is dominated by semidiurnal $(12.4 \mathrm{hr}$ period) tidal forcing. The damping influence of the shallow sill near Thumb Island (westernmost end of Liverpool Bay) and constriction through the fingers delays the tide inside the Eskimo Lakes by approximately four hours and reduces its amplitude to about a half of the outside value $(0.1 \mathrm{~m}$ versus $0.2 \mathrm{~m}$ ). On the other hand, the flow velocities at E600 inside the Eskimo Lakes are higher than at E800 in Liverpool Bay $\left(0.6 \mathrm{~m} \mathrm{~s}^{-1}\right.$ versus $\left.0.1 \mathrm{~m} \mathrm{~s}^{-1}\right)$ because flow is constrained and accelerated at the fingers. The fingers also constrain cross-channel motions, and thus currents in Liverpool Bay rotate through tidal cycles (cf. Fig. 6a), whereas currents in the Eskimo Lakes are aligned along the channel axis (Fig. 6b).

It is also possible that oscillations within the Eskimo Lakes are related to externally forced surges that propagate into the system from offshore (see Henry and Heaps, 1976). Evidence of a minor surge propagating under the fast ice cover is shown by the steady rise in water level between 

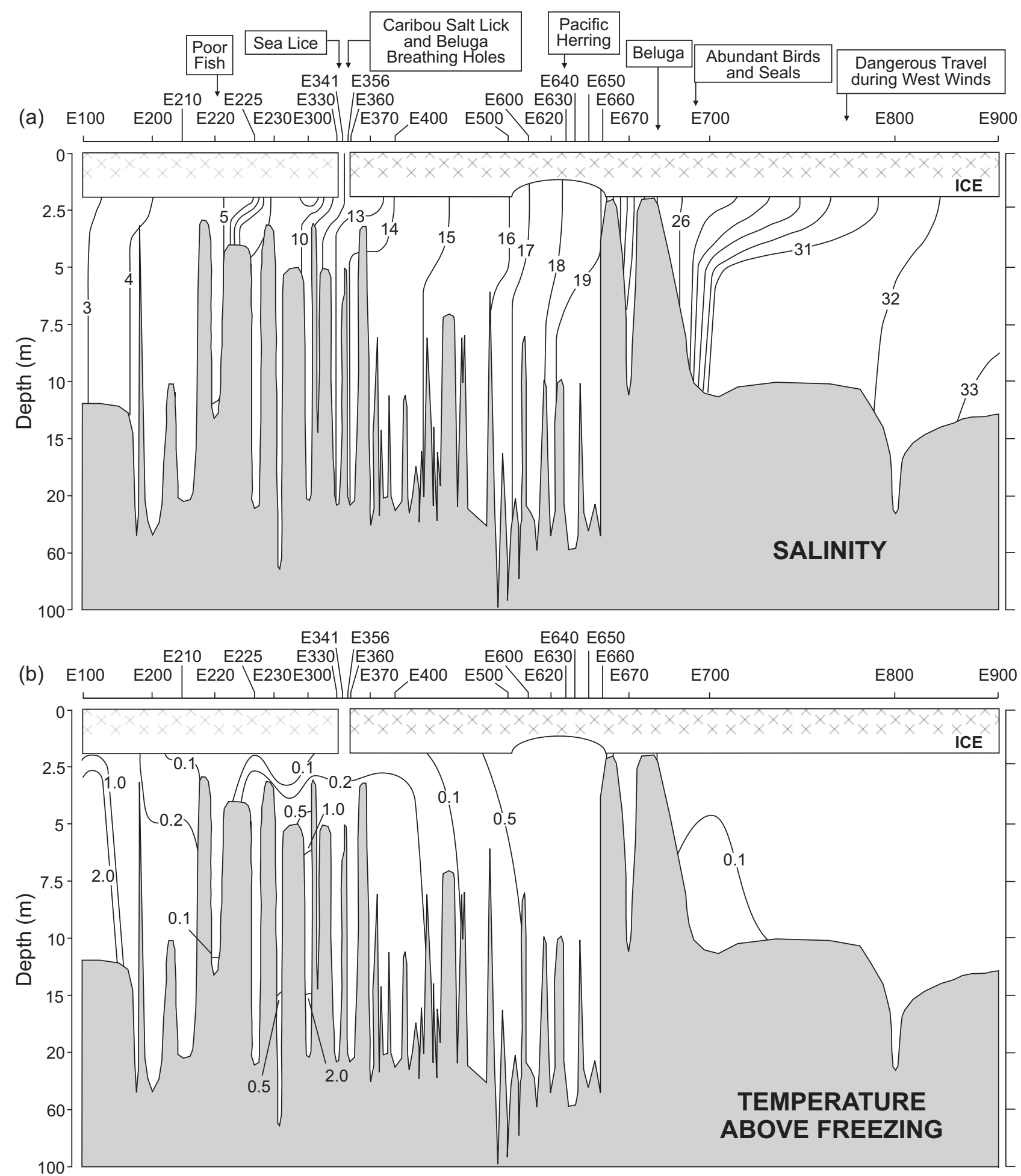

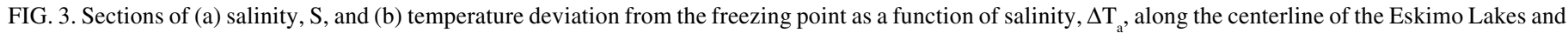

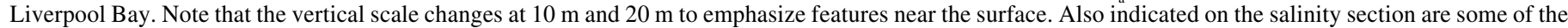
observations supplied by Jimmy Jacobson. The distance along the station line of the section is about $300 \mathrm{~km}$.

19 and 24 April (Fig. 5) and by the dominance of flows into the system (westward) during this period (Fig. 6).

The volume of water exchanged during one tidal cycle is calculated as follows. Taking the cross-section of the channel near E600 to be $10^{4} \mathrm{~m}^{2}$ and using the mean velocity over one-half tidal cycle (assuming boundary layer effects are small), the tidal transport through the channel is found to be near $5 \times 10^{3} \mathrm{~m}^{3} \mathrm{~s}^{-1}$, or somewhat larger than the wintertime flow of the Mackenzie River.

Tides also influence mixing in the estuary. In general, mixing and horizontal exchange in estuaries are caused by a combination of river inflow, winds, and tides. In winter- 


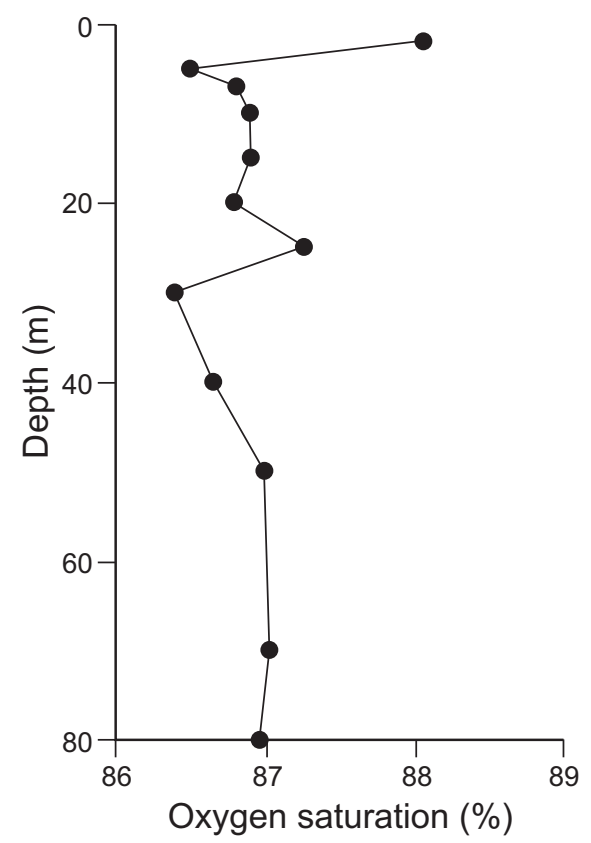

FIG. 4. Profile of percent saturation of dissolved oxygen in the middle (deepest) basin of the Eskimo Lakes (E500).

time, the river flows into the Eskimo Lakes are weak, and the landfast-ice cover all but eliminates wind effects. Tidal excursions, while present, are not particularly large (Fig. 5). Why, then, is mixing, as evidenced by large horizontal gradients, so pronounced in this system? The most likely explanation relates the complex shoreline and bathymetry of the lake to the phenomenon of tidally induced shear dispersion. In the discussion below, we follow closely the theoretical overview given by Geyer and Signell (1992).

Dispersion refers to the local spreading of a patch of fluid to an adjacent area. The term "shear dispersion" means that variation in the flow with depth or distance causes a parcel of fluid to be strained in the direction of flow into a long thin filament, so that the effects of transverse diffusion are greatly enhanced (Taylor, 1954; Fischer et al., 1979). Shear flow in natural bodies of water is especially predominant near topographic and bathymetric irregularities where eddies are formed. To see the importance of this effect, we follow Geyer and Signell (1992) and note that the value of turbulent diffusivity $\left(\mathrm{K}_{\text {turb }}\right)$ in a well-mixed estuary can be approximated by

$$
\mathrm{K}_{\mathrm{turb}}=\mathrm{C}_{\mathrm{d}} \mathrm{U}_{\text {tide }} \bullet \mathrm{h}
$$

where $\mathrm{Cd} \sim 0.003$ is a quadratic drag coefficient, $\mathrm{U}_{\text {tide }}$ is the tidal velocity, and $\mathrm{h}$ is water depth. Similarly, the value for the coefficient of dispersion ( $\mathrm{K}_{\text {disp }}$ ) is given by

$$
\mathrm{K}_{\text {disp }}=\mathrm{C}_{\mathrm{s}} \mathrm{U}_{\text {tide }} \cdot \mathrm{h}
$$

where $\mathrm{C}_{\mathrm{s}} \sim 0.15$ is an empirical constant for oscillatory flows. It follows that the ratio of the two coefficients $\mathrm{K}_{\mathrm{disp}} /$ $\mathrm{K}_{\text {turb }} \sim 0.15 / 0.003 \sim 50$. Hence, shear dispersion in such

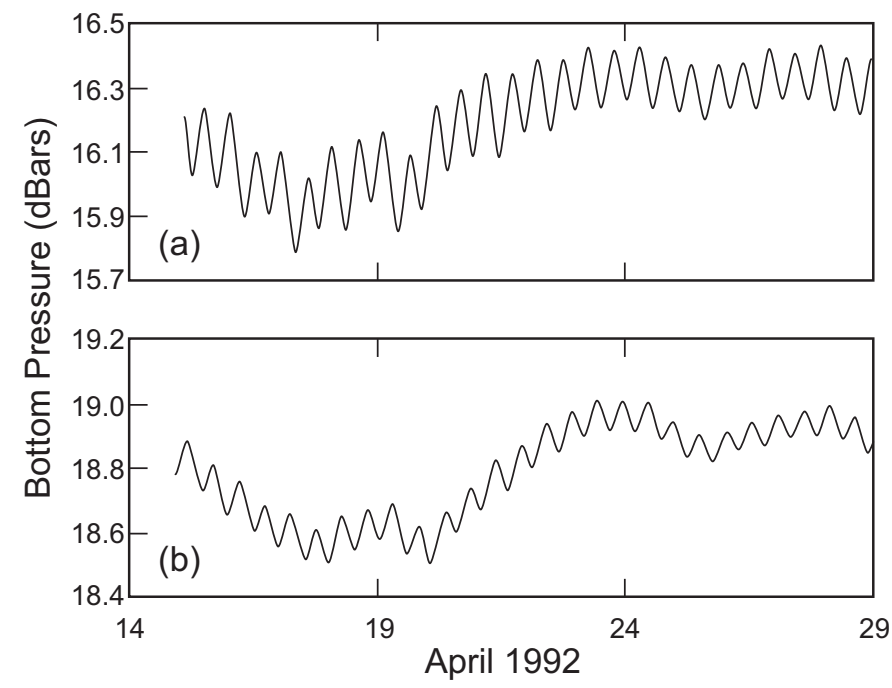

FIG. 5. Time-series plots of bottom pressure at stations in (a) Liverpool Bay (E800) and (b) the Eskimo Lakes (E600).

cases can magnify the mixing effects of turbulent diffusion by one or two orders of magnitude, leading to the so-called "explosive mixing" condition for geophysical flows.

The modeling studies of Signell and Geyer (1991) demonstrate another critical point related to shear dispersion. The explosive mixing effect is locally limited to the distance $\left(\mathrm{L}_{t}\right)$ that a parcel of water moves over one tidal cycle (the tidal excursion length). This means that the effects of enhanced mixing around a shoreline promontory are locally confined and thus have only a small impact on the large-scale transport of material within an estuary. However, when irregularities are sufficiently close so that eddies overlap and interact, a type of relay or "dynamical hand passing" occurs from one eddy to the next, and material is dispersed rapidly from one local zone to another. The complex shoreline and bathymetry of the Eskimo Lakes are optimal for the relay of materials through shear dispersion.

Averaging the velocity measurements shown in Figure 6 over one-half tidal cycle yields an estimate of $\mathrm{L}_{\mathrm{t}}=20 \mathrm{~km}$. In the vicinity of the fingers, the typical spacing of shoreline features normal to the flow $\left(\mathrm{L}_{\mathrm{s}}\right)$ is 2 to $4 \mathrm{~km}$, which is similar to the typical spacing of bathymetric features (sills and basins): $\mathrm{L}_{\mathrm{b}}=2$ to $4 \mathrm{~km}$. Hence, $\mathrm{L}_{\mathrm{t}}>>\mathrm{L}_{\mathrm{s}} \sim \mathrm{L}_{\mathrm{b}}$, and tidal dispersion is expected to contribute significantly to material transport (Signell and Geyer, 1991).

Value

The initial insight afforded by Jimmy Jacobson led to the conclusion that an accurate description of tidal dynamics and coupling to Liverpool Bay, as shown conceptually in Figure 7, is required before any ecological or policy model can be developed for this system. For example, at least three points arise from this simple look at mixing in the Eskimo Lakes. First, that properties such as contaminants or nutrients may be transported rapidly up the estuary by tidal 


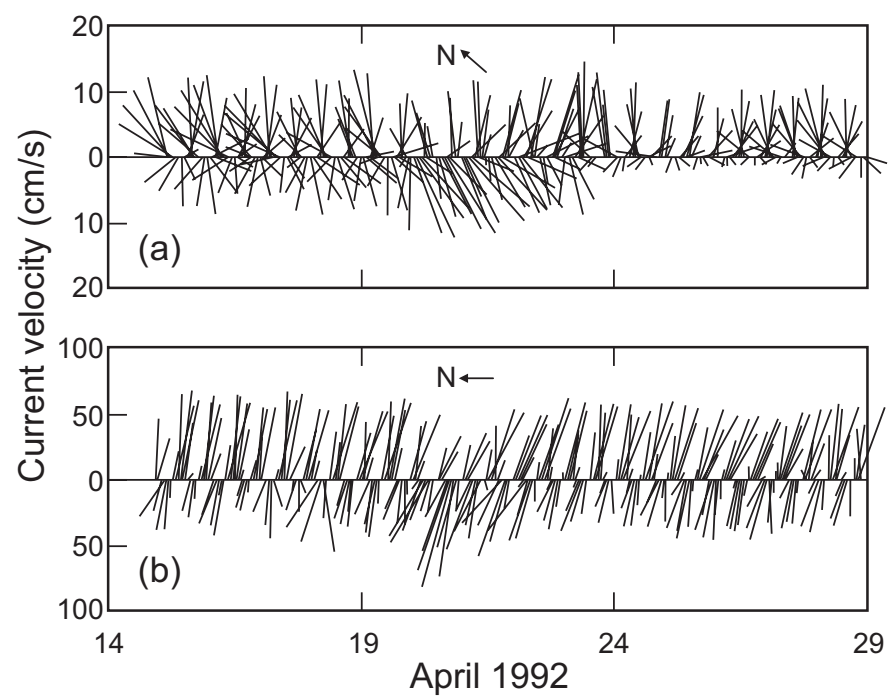

FIG. 6. Time-series plots of the along-channel current velocity in the Eskimo Lakes for (a) Liverpool Bay (E800) and (b) the Eskimo Lakes (E600). The stick vectors have been oriented so that the up direction refers to the along-channel eastward flow.

dispersion. Second, especially strong mixing may be expected near fingers, and this may explain Jacobson's observation that "blue herring" (Pacific herring Clupea pallasii pallasii) are especially abundant in this area, where they apparently aggregate to spawn (Fisheries and Oceans Canada, 2007). Other species that aggregate in the Eskimo Lakes and provide subsistence opportunities include lake trout, ringed seals, beluga and migratory birds. Third, because shear dispersion itself is a very patchy process, any future quantification of mixing will require attention to complex motions and detailed modeling. Indeed, it is clear that the remarkable zonation of the lakes' biology (e.g., Evans and Grainger, 1980) is tied to strong vertical mixing in narrow reaches and the subsequent upwelling and recycling of nutrients that support primary production.

\section{THIN ICE CONDITIONS}

\section{Setting and Narrative}

An interesting feature of the estuary is the narrow and shallow passage (approximately $100 \mathrm{~m}$ wide and $8 \mathrm{~m}$ deep) through a finger that separates the two middle basins of the Eskimo Lakes (Fig. 2d; 69 $12.5^{\prime} \mathrm{N}, 132^{\circ} 27.0^{\prime} \mathrm{W}$ ). When we told Jimmy we wanted to obtain water samples by landing on the ice by helicopter and drilling ice holes, he felt obliged to warn us to be very careful at this particular location, saying "The water there stays open year round, no matter how cold it gets." He went on to tell us how the caribou liked to come to this spot to use it as a salt lick and how the open-water area was a kind of last-chance breathing hole for "greedy" beluga who had lingered too long in the upper lake system before freeze-up and were facing suffocation or starvation. This manifestation implies the

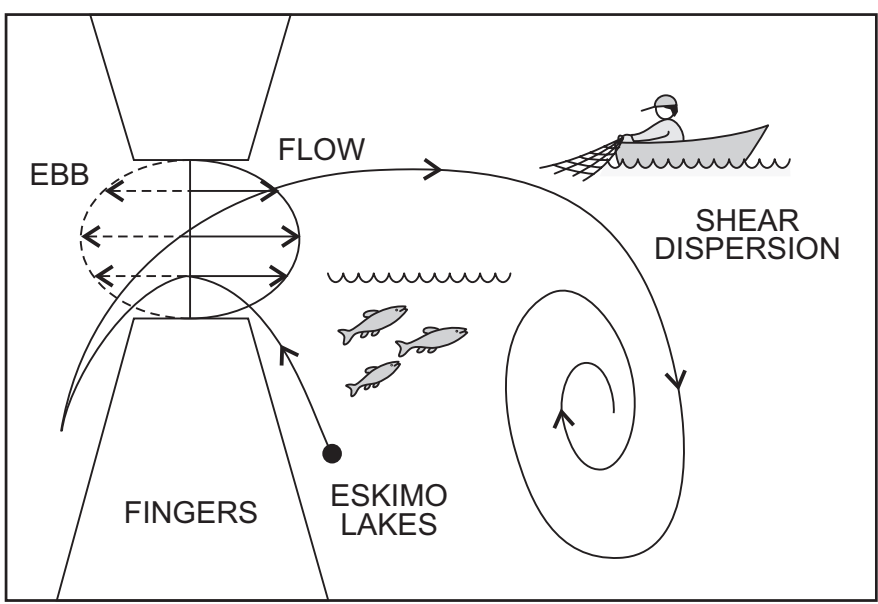

FIG. 7. A schematic (plan view) showing how the ebb and flow of tide through narrow passages at the entrance to the Eskimo Lakes enhances mixing, which in turn supports a biologically rich ecosystem for Pacific herring (J. Jacobson, pers. comm. 1992), cod, and bottom fish such as starry flounder Platichthys stellatus and arctic flounder Liopsetta glacialis (M. Lawrence, pers. comm. 1992) that is an important source of country foods.

presence of strong flows under the winter ice cover, as well as the subsequent upward mixing of heat (and nutrients) from subsurface depths. We later learned that because of its abundant food resources, this finger had once been the site of an Inuit settlement called Saunaktuk (Arnold, 1986). We will refer to the channel by this name.

\section{Observations and Analysis}

After hearing Jimmy's account, we visited the site and, indeed, found a small area of open water and thin ice (ca. $1000 \mathrm{~m}^{2}$ ) at the eastern entrance of Saunaktuk Channel. The water was fast-flowing and had temperatures well above freezing immediately below the ice-water interface.

Why does the area remain ice free? There appears to be a combination of two reasons. First, because of salinity (density) stratification, heat from the previous summer is trapped below the surface layer, as shown in Figure 3b. Second, flow velocities are sufficiently high to yield a turbulent heat transport upwards that balances heat loss to the atmosphere. This theory can be tested with a simple model. Flows required to maintain open water can be determined using the empirical relation for under-ice heat flux (H) derived by Hamblin and Carmack (1990)

$$
\mathrm{H}=\mathrm{q} \mathrm{c}_{\mathrm{p}} \mathrm{C}_{\mathrm{d}} \Delta \mathrm{T}_{\mathrm{a}} \mathrm{U}_{1}^{2}
$$

where $\mathrm{q}$ is density, $\mathrm{c}_{\mathrm{p}}$ is specific heat $4217 \mathrm{~J} \mathrm{~kg}^{-1}{ }^{\circ} \mathrm{C}^{-1}, \mathrm{C}_{\mathrm{d}}$ is an empirical constant evaluated for smooth ice conditions to be $0.8 \times 10^{-3}, \Delta \mathrm{T}_{\mathrm{a}}$ is the deviation from the freezing-point temperature for water (here referenced to $1 \mathrm{~m}$ depth), and $\mathrm{U}_{1}$ is the boundary layer-scale velocity measured at $1 \mathrm{~m}$ depth.

We measured $\Delta \mathrm{T}_{\mathrm{a}}=0.28^{\circ} \mathrm{C}$ using a portable CTD recorder, which we lowered into the open hole by carefully crawling across the thin ice. At present, we have no direct 


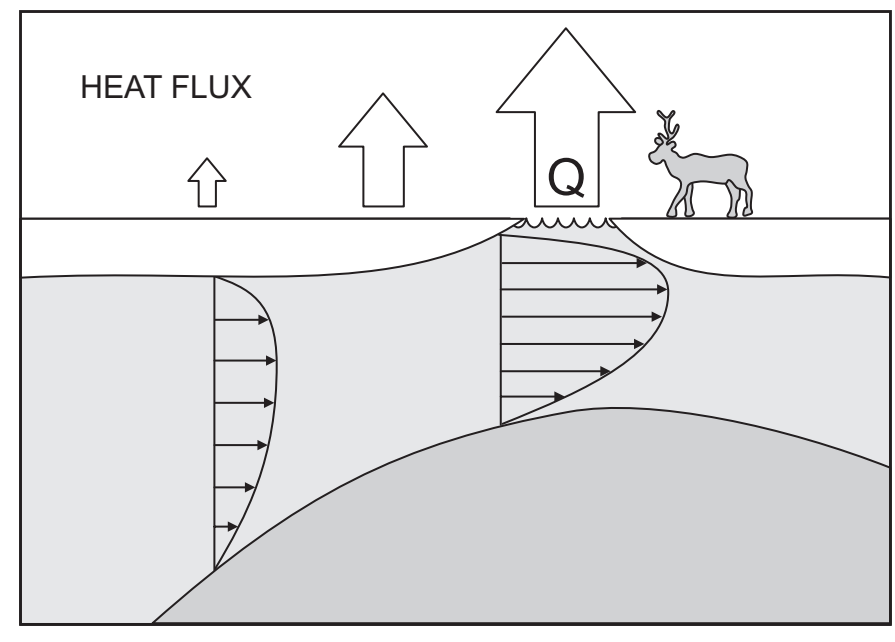

FIG. 8. A schematic diagram showing how accelerated flow through constrictions or over sills enhances heat flux to the bottom of the ice, producing either open water or thin ice. These locations provide opportunities (salt for caribou, breathing locations for trapped beluga) as well as risks (falling through thin ice during winter travel).

measurements of velocity below thin ice; however, the above model can be evaluated to estimate velocity by setting $\mathrm{H}$ equal to a value typical of open-water heat flux at this latitude in midwinter; an appropriate value is $300 \mathrm{~W} \mathrm{~m}^{-2}$ (see Hamblin and Carmack, 1990, for discussion). Then $\mathrm{U}_{1}$ is found to be on the order of $0.6 \mathrm{~ms}^{-1}$. From this evaluation we conclude that flow velocities exceeding about 1 knot may result in the thinning of ice or open water.

\section{Value}

The thinning of ice at certain locations of accelerated flow (Fig. 8) creates circumstances that may benefit caribou, trap beluga, or provide hidden risks to those who travel across the ice. A practical benefit from this example relates to travel safety during winter, when low light and snow conditions can make thin ice difficult to spot. With a modest survey and modeling effort to determine the distribution of currents, it should be possible to produce maps delineating areas that are prone to thin ice so that winter travelers can avoid them.

\section{ICE SHOVES AND FLOODING OFF TUKTOYAKTUK PENINSULA}

\section{Setting and Narrative}

The Mackenzie Inuit who occupied the delta region were almost completely killed off by smallpox and other diseases in the early post-contact period (McGhee, 1988). With them was lost much traditional knowledge specific to the region. Thus, when the area was re-occupied by Inuit from Alaska, many aspects of survival and safety specific to this region had to be re-learned. The danger of ice shoves and flooding off the Tuktoyaktuk Peninsula near
Nuvurak (Point Atkinson) is an excellent example. According to Jimmy's memory, "a lot of old-timers died" relearning this lesson, which is a good example of Native innovation, hypothesis testing, and experimentation, with the added risk that a bad experiment may be fatal. Because the NOGAP study group was unfamiliar with the dangers of traveling and camping near the coast, Jimmy felt obliged to pass this information on to us.

One lesson learned is not to camp overnight on the ice in the region immediately offshore of Point Atkinson: "Either camp up on the land, or go further out to sea," Jimmy instructed us. In winter soon after freeze-up is the worst time, he said: "Most of the old people froze to death in January; that is the bad month." Flooding was the result of northerly winds over open water offshore, which forced water up and over thin and relatively weak bottom-fast ice near the coast. Occasionally, flooding would be accompanied by plates of ice shoving over each other, which would cause water to soak the snow, including the igloos of hunters camped on the ice, and thus cause death by freezing.

\section{Observations and Analysis}

Our work on the Beaufort Shelf led us to conclude that landfast ice in the Mackenzie Estuary forms exclusively via a top-down process, in which heat lost to the atmosphere at the surface of the ice results in ice growth at the bottom of the ice (Macdonald and Carmack, 1991; Macdonald et al., 1995, 1999). There are, however, other ways that sea ice cover can form. In the Southern Ocean, for example, heavy snowfall can accumulate sufficiently to sink the ice so that water from beneath floods it and then freezes in a bottom-up process (Lange et al., 1990). The two contrasting processes give themselves away in the ice through the oxygen isotope $\left(\delta^{18} \mathrm{O}\right)$ and salt composition, as well as through the structure of the ice itself. Seawater is salty and isotopically heavy compared to snow or runoff from land, which are not salty and isotopically light. Upon hearing Jimmy's narrative of overflooding in the Beaufort's nearshore, we formed a hypothesis that flooding of coastal ice, if it occurred, should be recorded in the oxygen isotope $\left(\delta^{18} \mathrm{O}\right)$ and salinity composition of an ice core, as illustrated schematically in Figure 9. When ice grows from water in the top-down process, the $\delta^{18} \mathrm{O}$ composition follows that of the water, with a positive (heavier) offset (fractionation) of 2.6\%o (see, e.g., Macdonald et al., 1995). Therefore, isotopically heavier water (high $\delta^{18} \mathrm{O}$ ) reflects ice grown from seawater, while isotopically light water reflects ice grown from river water or ice that contains precipitation (low $\delta^{18} \mathrm{O}$ ). Along the Tuktoyaktuk coast, when landfast ice is forming in the top-down process, the $\delta^{18} \mathrm{O}$ and salinity at the ice-water interface typically decrease through winter as inflow from the river spreads below the ice (Macdonald et al., 1995). This situation is shown in Figure 9, where the ice exhibits a constant salinity $(4-5)$ and $\delta^{18} \mathrm{O}(-8 \%$ ) below about $50 \mathrm{~cm}$. These values represent ice growing from representative seawater along 


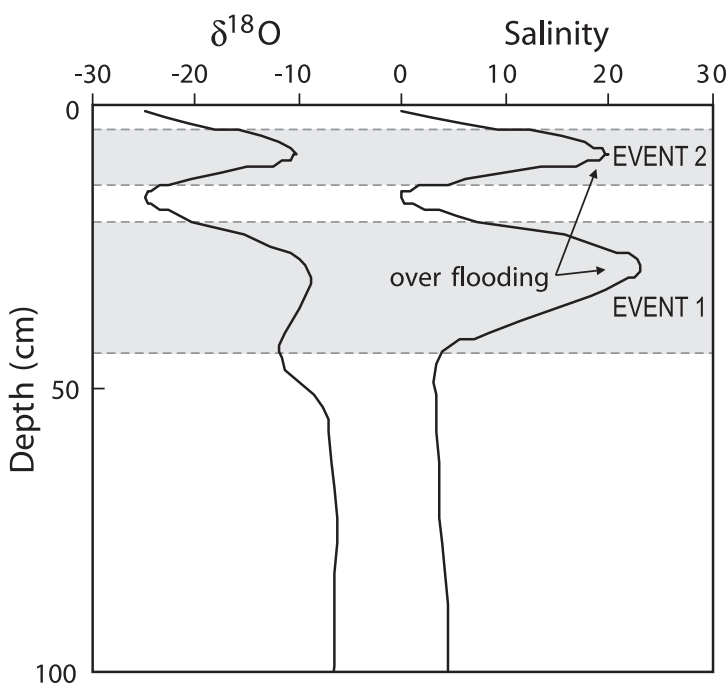

FIG. 9. Schematic of $\delta^{18} \mathrm{O}$ and salinity profiles in ice that has been subjected to two hypothetical overflooding events. The properties of ice accumulated during the hypothetical overflooding events were produced by using real data from the ice core shown in Figure 10a. To construct the flooded core, we have assumed that the ice was first flooded by $20 \mathrm{~cm}$ of water with properties consistent with 90-100 cm in the core in Figure 10a, and then again with $13 \mathrm{~cm}$ of water consistent with properties from 150 to $160 \mathrm{~cm}$ in the same core. Between the flooding events, we have added $3 \mathrm{~cm}$ of snowfall (water equivalent). Water properties and time frame for the overfloodings were projected from the ice core (Fig. 10a) according to procedures in Macdonald et al. (1995).
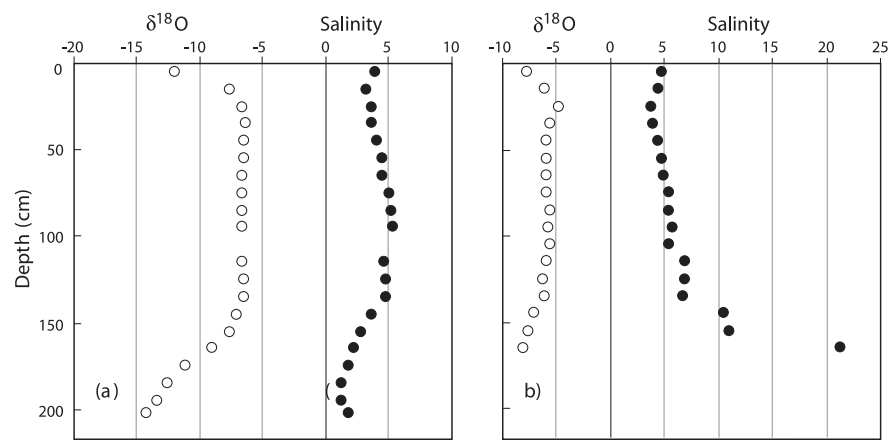

FIG. 10. $\delta^{18} \mathrm{O}$ and salinity profiles from ice cores collected from a nearshore location (15 m water depth) within the Mackenzie Shelf/Estuary (Core 1, panel a), and in the ice shove zone ( $2 \mathrm{~m}$ water depth) to the west of Nuvurak near Point Atkinson (Fig. 1) on 12 May 1992 (Core 2, panel b). Locations are shown on Figure 1.

the coast toward freeze-up (e.g., salinity of $\sim 23$ and $\delta^{18} \mathrm{O}$ of $-10.6 \%$ ). Two hypothetical overflooding events have been placed in the top $50 \mathrm{~cm}$ of the ice, and the record that these events would leave has been created by taking seawater properties during winter and placing this water on top of the ice, where it rapidly freezes. Because this water is trapped by rapid freezing, it has much higher salinity (cannot drain its brine) and is lighter isotopically (cannot fractionate its oxygen isotopes). In Figure 9, we have interbedded the two freezing events with a few centimetres of snowfall, which can be seen as strong excursions to low salinity and $\delta^{18} \mathrm{O}$ at the surface of the ice and at about $15 \mathrm{~cm}$ (between the two overflooding events).

Accordingly, we collected two ice cores off Nuvurak (Point Atkinson), the area Jacobson identified as being

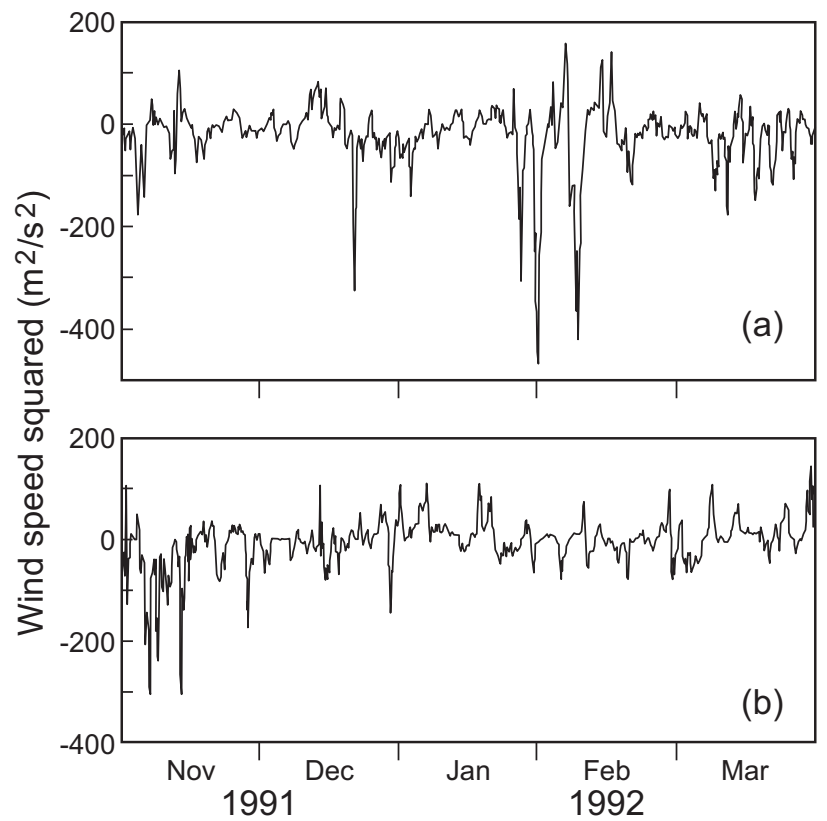

FIG. 11. Wind records at Tuktoyaktuk for (a) November 1990 to March 1991 and (b) November 1991 to March 1992 (data from Environment Canada).

prone to overflow (see Fig. 1). Our results (Fig. 10a, b), however, reveal no overflooding near the surface of these two coastal ice cores. Instead, the dominant signals in these cores are a small layer of isotopically light ice near the surface (snow/precipitation) and a drift to lighter, fresher ice below about $150 \mathrm{~cm}$, which is due to the invasion of Mackenzie Plume water (Macdonald et al., 1995). Apparently, winds in January and February of 1992 (Fig. 11b) were insufficient to initiate flooding. The 1991 wind record (Fig. 11a) indicates that flooding events might have been more likely to occur in that year, but unfortunately, Jimmy had not yet alerted us to this process. The hypothetical ice core with two overflooding events (Fig. 9) was based on the properties expressed in the ice core shown in Figure 10a.

\section{Value}

Better understanding of nearshore flooding relates not only to safety when traveling and camping on the ice during winter (Fig. 12), but also to offshore development, placement of offshore platforms, seismic and other exploration activities, pipeline and ice road construction, and the potential behavior of oil spills. While this flooding process has been identified off Nuvurak, similar events likely occur elsewhere along the coast and should be identified prior to development. In the Arctic Ocean, sea ice has been viewed as forming by freezing at the bottom simply because the low winter precipitation does not supply enough snow to weight the ice to the point of overflooding. However, if Arctic coastal regions are subject to overflooding due to surges brought on by open water and winds from the north, then recent declines in summer ice cover (e.g., Stroeve et al., 2007) may well 


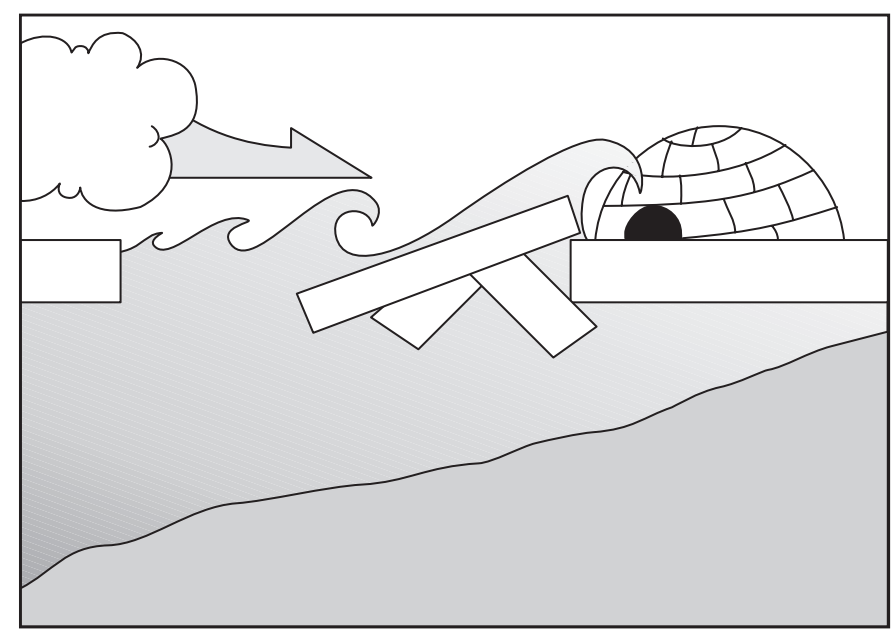

FIG. 12. A schematic diagram showing the risks from storms and surges that produce ice motion (shoves) and overflooding. These phenomena are most likely to occur during freeze-up in the embayments north of the Tuktoyaktuk Peninsula.

manifest in increased production of nearshore ice through overflooding. This process alters ice properties, including thickness and whether or not the ice is frozen to the seabed, which then may alter nearshore breakup in the following spring. Isotope and salinity records in ice offer the potential, at least, of surveying and assessing large areas for their susceptibility to overflow and relating the extent of overflooding to wind velocity. The potential for onshore transport of water can be evaluated from a model of winddriven set-up (Henry and Heaps, 1976; Kowalik, 1984).

\section{DENSE SHELF WATER FORMATION IN LIVERPOOL BAY}

\section{Setting and Narrative}

In 1991, the field party was mapping the under-ice spreading of new (winter-supplied) Mackenzie River water on the shelf. Before the group went to Liverpool Bay and Cape Bathurst, Jimmy recounted his experiences in traveling on the ice in Liverpool Bay, again through concern for our safety.

Jimmy told us that when the winds were absent or from the west, the ice cover would remain fixed and safe for travel in Liverpool Bay. But, when the winds came from the east and the tides were large, leads would open rapidly in the ice. He told of one time when he was working as a guide for an oil exploration party crossing Liverpool Bay with heavy tractor rigs. He had warned the foreman that conditions were poor, but this foreman had thought otherwise. Jimmy then warned the driver of the rig to at least keep his door open. At one refrozen lead the ice parted and the rig went in, but the driver jumped free. Jimmy recalls that by the time the driver stood up and looked around, the rig was gone. "Where's my rig?" the man said.

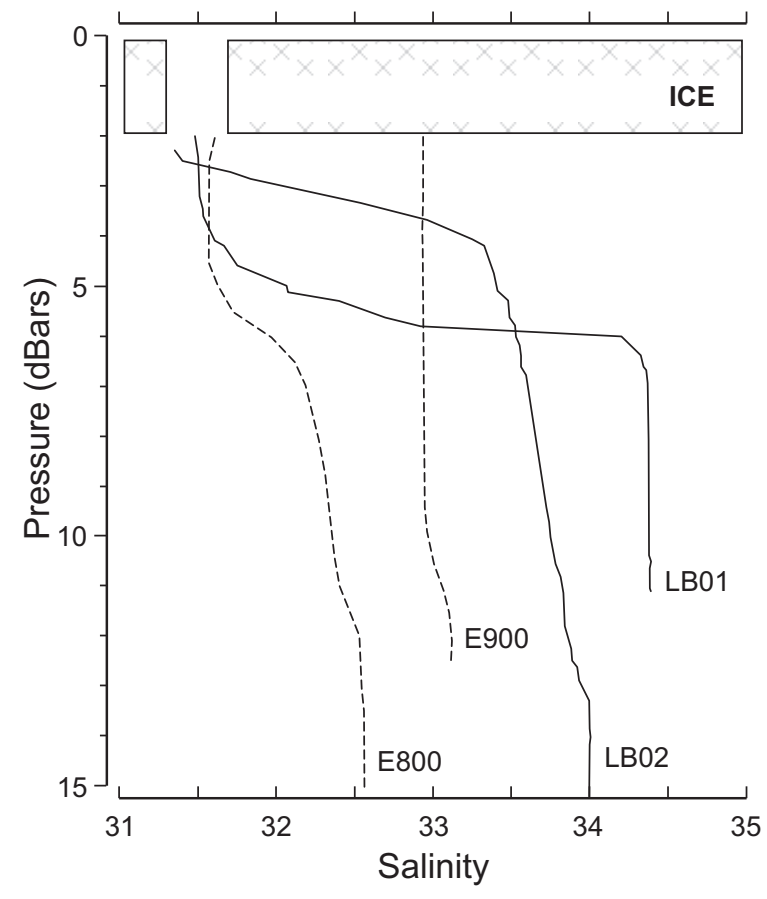

FIG. 13. Salinity profiles from Liverpool Bay in May1991 (LB stations) and May 1992 (E stations).

\section{Observations and Analysis}

Jimmy's narrative about the rig is interesting because it gives a clue about the wintertime formation of dense, saline water on shallow continental shelves and its subsequent drainage into the ocean interior. While several authors have implicated shelf drainage as an important source of mid-depth halocline water (for a review, see Carmack, 1990), supporting data are rare (Melling, 1993; Melling and Moore, 1995). It may be that drainage from semienclosed Arctic bays is an important regional source of brine. For example, V.I. Pomamaraev (pers. comm. 1992) reports similar findings from Arctic shelves in Russia (i.e., Kolychin Bay, Cross Bay, Provideniya Inlet, Shelikov Bay, Tugur Bay, and Peter the Great Bay). He notes that during winter cold, high-salinity water is typically found only in shallow, semi-enclosed bays in which polynyas form and multiple episodes of ice formation occur.

H. Melling (pers. comm. 1992), who has monitored winter conditions on the open Beaufort shelf since 1981, has documented strong interannual variability. Jimmy Jacobson's observations give one possible reason, at least for local brine buildup: wind direction. If winds continually drive divergence in the ice field, more open water is exposed, more ice is formed, and more saline water is produced. Figure 13 shows salinity profiles from the mouth of Liverpool Bay from May 1991 and May 1992. Note that in 1991 the bottom salinity is 1 to 2 higher than in 1992.

According to Grainger and Evans (1982) the salinities in Liverpool Bay in late summer are typically 17 to 20 ; in contrast, our data show winter values between 26 and 34, an 


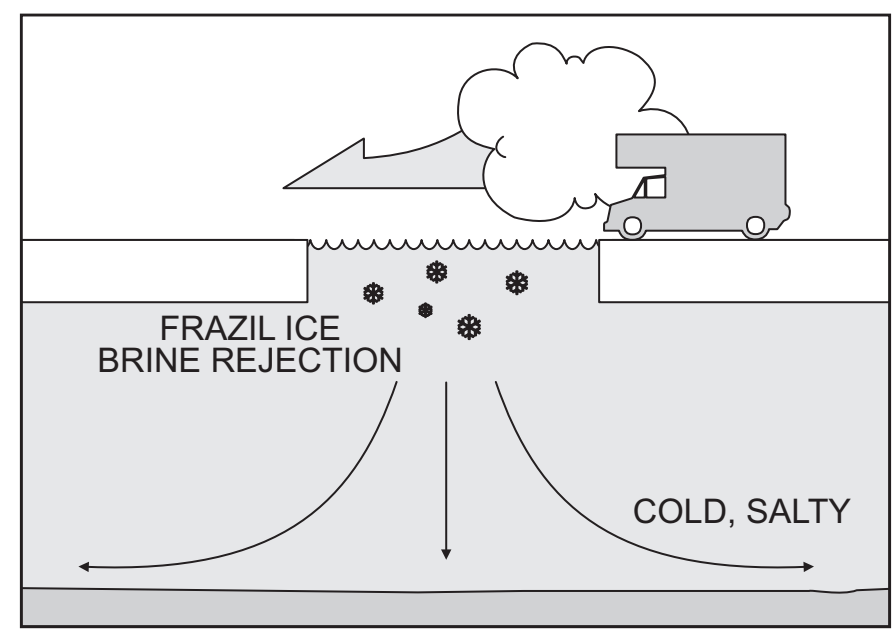

FIG. 14. A schematic diagram showing that winds leading to ice divergence favour the production of brine in Liverpool Bay, but also make vehicle travel on the ice risky.

average increase of more than 10. Can this salt be supplied by the rejection of brine by growing sea ice? Consider the following simple budget. About $20 \mathrm{~kg}$ of salt is rejected from each cubic meter of ice grown from seawater of average salinity 28 (Macdonald and Carmack, 1991). Typically, about $2 \mathrm{~m}$ of ice forms annually; thus, $40 \mathrm{~kg} \mathrm{~m}^{-2}$ of salt is injected into the underlying water. If this salt sinks and mixes with underlying water with an average depth of $5 \mathrm{~m}$, then a salinity increase of about 8 can occur, which is close to the required difference. Salinity increase could also be supported by winds prior to freeze-up in autumn that drive low-salinity surface waters offshore, replacing them with higher-salinity waters from depth. Another source of salinity increase is the deformation of the ice cover into leads and ridges, as well as its direct removal by ice drift, which allows additional volumes of ice to form and increases the local salt flux (cf. Melling and Lewis, 1982). Such effects must also counter the tendency for near-bottom density currents to drain the bay of excess salt.

From Jimmy's narrative, we conclude that winds from the east increase ice divergence and thus favor salt buildup in the bay. Figure 11 shows that 1991 was potentially a good year for brine production and a bad year for safe travel across the ice.

\section{Value}

An ongoing question in Arctic oceanography is the relative importance of processes contributing to exchange of water masses and material properties between the shelf and ocean interior. A potentially important but poorly understood process is the transport of regenerated nutrients and resuspended organic matter in cold, brine-rich density flows. It follows that a better understanding of shelf exchange processes, especially one based on data and observation, should advance our ability to model such processes in Arctic systems. From this work, we cannot claim that Arctic bays are important at the global scale, but they do provide a laboratory in which to examine processes. Furthermore, a better appreciation of the effect of wind direction on the deformation of ice will lead to safer winter travel and operations (Fig. 14).

\section{DISCUSSION AND CONCLUSIONS}

\section{Biological Distributions and Productivity}

Much of our emphasis on the value of indigenous knowledge is based on the assumption that close dependence on the land for survival builds an intimacy with nature that most Western scientists simply do not attain. That northern Native science is keyed to survival is underscored by the fact that status comes to those who find food in times of scarcity. Jimmy Jacobson has vivid recollections of such experiences. For example, during one particularly difficult winter, Jimmy recalls one of the "old-timers" returning to the village to tell of how he had made a hole in the ice and located a good spot to fish. He told Jimmy to return to the central part of the lake and go just off a small pingo located on the finger. Jimmy followed these instructions and was able to relocate this one small hole in the ice. He fished the remainder of the night and returned home with 76 fish, leaving the good fishing hole "rimmed red with blood."

What is important about this recollection is that it is a point of pride and community respect that Jacobson was able to find abundant food at a time when food was in short supply. This illustrates both an ecological principle and its ethnological counterpoint: even when overall population abundances are low, as might be inferred from productivity estimates (e.g., Grainger and Evans, 1982), there still exist small, local "oases" where stocks are concentrated by flow patterns; the hero becomes, in fact, the indigenous scientist who can locate such oases.

Jacobson also described other observations that suggested an association between biological zonation and oceanographic mixing regimes within the system. For example, he noted that lake trout caught near the finger regions in the eastern and middle portions of the lake were high in fat content, whereas fish caught elsewhere, especially in the western reaches of the lake, were dry and had larger heads and thinner bodies. In describing the fingers at mid-lake, he noted that "fish caught from here were so rich you could cook them in their own fat." However, there was apparently an important negative aspect to this particular zone in that "You could not net fish under the ice downstream of the channel because there were so many sea-lice (amphipods) that they would eat your fish before you got your net out of the water." The eastern finger regions were also described as good places to catch the blue (Pacific) herring, a filter-feeding (planktivorous) fish (see McElderry, 1986; Fisheries and Oceans Canada, 2007). The fact that blue herring are concentrated in the eastern fingers is also borne out by Jacobson's story of seismic 
testing during oil exploration: "When they set off that dynamite, thousands of these fish came to the surface belly-up."

Especially rich places for fishing occur where creeks or rivers enter a moderately restricted bay and mix with seawater. For example, Jimmy described Tuktoyaktuk harbor as being one of the richest bays in the world. But, he noted, "You have to know how and where to set your nets," because there are certain places where fishing is especially good under the right wind conditions. Unfortunately, the best spot was located where the oil industry chose to build a dock, and they told Jacobson he could not fish there any longer because he would get in the way. Another such place where diverse waters mix is near Kugulak and in Kugulak Lake. Jacobson states that 14 different kinds of fish can be caught there (cf. Bond and Erickson, 1993). Given that biological diversity is generally quite small in Arctic aquatic ecosystems, this number is impressive.

A final narrative concerns the southwestern end of Liverpool Bay. Here, Jimmy told us, "the wind and currents mix the water and make it rich." He said that clams could be found in the area and that dogs would often dig them up. Again, we chose to test Jacobson's observations with measurements. While we doubted the presence of clams, we reasoned that an area of enhanced biological production would be reflected in the quality of bottom sediments, and thus asked our bottom-coring specialist (D. Paton) to fly to the site and obtain a core for analysis of organic material. Our results were of mixed success; Paton returned to say that he could not get the core device to penetrate the bottom-because it was covered with shells!

Two brief points of environmental significance emerge. The first is that the mixing of diverse water types may enhance productivity because each component supplies a nutrient or other property missing in other components. The second is that biological populations that are locally concentrated in time or space may far exceed the largescale mean and thus have far greater importance to indigenous life styles. These same populations are also at greater risk should development be pursued without adequate knowledge of biological distributions.

\section{Traditional Knowledge, Science, and Policy}

This work takes an approach that differs from that of classical ethnography, which emphasizes cultural description and the archiving of invaluable knowledge (see, for example, insightful works by Oakes et al., 2003; Turner, 2005; and Cruickshank, 2005). We admit that our first attempt to bridge the gap between indigenous knowledge and the methodologies of Western science has engaged only one elder, and we made no attempt to establish community priorities or consensus. We simply dialogued with an elder to gain perspectives based on his personal experiences, needs, and motivation, and then used these perspectives to focus our own inquiries. Oceanographers typically plan fieldwork around site locations to study particular phenomena: sometimes at a single point (a station), sometimes along a line (a section), or sometimes in a three-dimensional array (a station plan). Often the planning for such work is based on "oceanographic instincts," as dictated by ship time and regional accessibility, but retains a lot of the arbitrary. In fact, our initial work on the Beaufort Shelf was planned along these lines: we called it "putting dots on a chart." We wanted to develop a process whereby indigenous knowledge focused where and why we placed those dots.

How does this work fit into the broader field of indigenous knowledge? Colorado (1986) argued that recognition of the value of traditional knowledge for economic or societal gain is not enough: we must also accept all the means used by indigenous peoples, including the spiritual, to understand our place in the world. Booth and Jacobs (1988) state that the Native American worldview in which man and nature are one is precisely the missing ingredient in Western environmental stewardship, and it must be reintroduced to our way of thinking. Such a worldview is not necessarily intergenerational and is vulnerable to loss. We suggest that because both Western science and indigenous knowledge offer phenomenological explanation, both must be accepted in the context of the excellence of the practitioner, whether a scientist or an elder. The tension inherent in co-science allows for creative exchange between the two approaches to science once both are accepted.

It is increasingly apparent that marine ecosystems are in crisis because of over-extraction (e.g., Myers and Worm, 2003) and that our governance of oceans is not adequate to the paramount task of sustainability (cf. Gunderson and Holling, 2002). Ecosystem-based management has been advanced as a way of correcting management mismatch among system components, but Young et al. (2007) argue convincingly that practical application of such management has thus far proved illusive. Instead, they advocate what they call "place-based management": integrated management of system components is carried out within a spatially well-defined and demarcated area. We propose that a major stumbling block in managing biological resources in the oceans has been the difficulty of entraining appropriate science into policy. To a large degree, this is a problem of communication. We suggest that the approach of drawing upon indigenous knowledge to better focus measurements and models provides a practical way to define and understand place (spatial and temporal), to recognize the special qualities inherent in that place, and to bring acceptance of the science as a benefit to the people who would ultimately suffer from unsustainable practices. Turner et al. (2003) express a similar view, noting that indigenous peoples are drawn to areas they define as "ecological edges"- where diversity and natural capacity are enhanced-and that historically they have actively maintained such places.

Perhaps the greatest concern regarding development of the North is whether or not the value of indigenous 
knowledge will be recognized before it is lost. Jacobson noted that the benefits brought by the white man, such as education, mechanization, and government support, have drawn indigenous people into larger population centers and weakened their traditional needs and skills. "Us oldtimers are dying off," he stated. Jacobson had two attributes that defined his excellence: one, his first language was the language of the land, a language developed to encode information needed for survival; and two, his survival and the survival of his family depended entirely on his own skills of travel and procuring food. These two attributes defined Jimmy's doctorate.

Today we recognize the error of many early polar explorers, who held on to the belief that their ways were best - sometimes with fatal consequences - and thus failed to see what the Inuit had achieved in developing techniques of dress, diet, and travel remarkably well adapted to their environment. Are we making the same arrogant mistake today by not seeking first to understand "place" and the true value of indigenous knowledge before attempting to apply Western science and engineering methods in the North?

\section{ACKNOWLEDGEMENTS}

We would like to express our appreciation to the NOGAP team: Doug Sieberg, Mary O'Brien, Rick Pearson, Fiona McLaughlin, Dave Paton, Darren Tuele, and Janet Barwell-Clarke. We are grateful to Tom Juhasz for providing assistance in mooring deployment and recovery. We acknowledge that this kind of work would be very difficult without the logistical support of the Polar Continental Shelf Project base in Tuktoyaktuk, and thank Barry Hough and Claude Brunet for their support; we thank our skilled pilots, Ron Sprang and Pierrette Paroz, for getting us to and from the ice safely. Craig Gerlach, Knut Aagaard, and one anonymous reviewer provided invaluable suggestions in preparing the final manuscript. We especially thank Jackie Jacobson for his services as guide and field technician, Bella Jacobson for her hospitality, and Fighto, the Jacobson husky, who stood on guard for us. This work was financially supported by Indian and Northern Affairs Canada and Fisheries and Oceans Canada.

\section{REFERENCES}

ACIA. 2005. Arctic climate impact assessment. New York: Cambridge University Press. 1042 p.

ARNOLD, C. 1986. Archaeological investigations in the Mackenzie Delta and Eskimo Lakes, 1985. Manuscript Report 2495. Ottawa: Archeological Survey of Canada, Canadian Museum of Civilization. 99 p.

BASSO, K.H. 1996. Wisdom sits in places: Landscape and language among the Western Apache. Albuquerque: University of New Mexico Press. 191 p.

BERGER, T.R. 1985. Village journey: The report of the Alaska Native Review Commission. New York: Hill and Wang. 202 p.
BOND, W.A., and ERICKSON, R.N. 1993. Fisheries investigations in coastal waters of Liverpool Bay, N.W.T. Canadian Manuscript Report of Fisheries and Aquatic Sciences 2204. Winnipeg, Manitoba: Fisheries and Oceans Canada.

BOOTH, A.L., and JACOBS, H.M. 1988. Environmental consciousness - Native American worldviews and sustainable natural resource management: An annotated bibliography. Council of Planning Librarians Bibliography 214. 40 p.

BRUNSKILL, G.J. 1986. The Mackenzie River Basin. In: Davies B.R., and Walker K.F., eds. The ecology of river systems. Dordrecht, The Netherlands: Dr. W. Junk Publishers. 435-471.

CARMACK, E.C. 1990. Large-scale physical oceanography of polar oceans. In: Smith, W.O., ed. Polar oceanography, Part A: Physical science. New York: Academic Press. 171-222.

CARMACK, E. C., MACDONALD, R.W., and PAPADAKIS, J.E. 1989. Water mass structure and boundaries in the Mackenzie Estuary. Journal of Geophysical Research 94:18043-18055.

COLORADO, P. 1986. Indigenous science. Edges 4:12-14.

CRUIKSHANK, J. 2005. Do glaciers listen? Local knowledge, colonial encounters and social imagination. Vancouver: UBC Press.

EVANS, M.S., and GRAINGER, E.H. 1980. Zooplankton in a Canadian Arctic estuary. In: Kennedy, V.S., ed. Estuarine perspectives. New York: Academic Press. 199-200.

FISCHER, H.B., LIST, E.J., KOH, R.C.Y., IMBERGER, J., and BROOKS, N.H. 1979. Mixing in inland and coastal waters. New York: Academic Press. 483 p.

FISHERIES AND OCEANS CANADA. 2007. Beaufort Sea large ocean management area: Ecosystem overview and assessment report. Winnipeg: Fisheries and Ocean Canada. 196 p.

GEYER, W.R., and SIGNELL, R.P. 1992. A reassessment of the role of tidal dispersion in estuaries and bays. Estuaries 15: 97-108.

GRAINGER, E.H., and EVANS, M.S. 1982. Seasonal variations in chlorophyll and nutrients in a Canadian Arctic estuary. Estuaries 5:294-301.

GUNDERSON, L.H., and HOLLING, C.S. 2002. Panarchy. Washington, D.C.: Island Press. 507 p.

GUSHUE, W., CARMACK, E.C., and MACDONALD, R.W., 1996. Freshwater inputs to Husky Lakes and Liverpool Bay. Canadian Technical Report of Hydrography and Ocean Sciences 175. 23 p.

HAMBLIN, P.F., and CARMACK, E.C. 1990. On the transfer of heat between a lake and an ice sheet. Cold Regions Science and Technology 18:173-182.

HENRY, F., and HEAPS, N.S. 1976. Storm surges in the southern Beaufort Sea. Journal of the Fisheries Research Board of Canada 33:2362-2376.

HUNTINGTON, H., and FOX, S. 2005. The changing Arctic: Indigenous perspectives. In: Arctic climate impact assessment. New York: Cambridge University Press. 61-98.

JOHANNES, R.E., ed. 1989. Traditional ecological knowledge: A collection of essays. Gland, Switzerland: IUCN - The World Conservation Union. 71 p.

KARI, J., and FALL, J.A. 2003. Shem Pete's Alaska: The territory of the Upper Cook Dena'ina. Fairbanks: University of Alaska Press. 400 p. 
KOWALIK, Z. 1984. Storm surges in the Beaufort and Chukchi seas. Journal of Geophysical Research 89:10570-10578.

KRUPNIK, I., and JOLLY, D., eds. 2002. The earth is faster now: Indigenous observations of Arctic environmental change. Fairbanks: Arctic Research Consortium of the United States. $384 \mathrm{p}$.

LANGE, M.A., SCHLOSSER, P., ACKLEY, S.F., WADHAMS, P., and DIECKMANN, G.S. 1990. ${ }^{18} \mathrm{O}$ concentrations in sea ice of the Weddell Sea, Antarctica. Journal of Glaciology 36: 315-323.

LEWIS, E.L., and PERKIN, R.G. 1983. Supercooling and energy exchange near the Arctic Ocean surface. Journal of Geophysical Research 88:7681-7685.

MACDONALD, R.W., and CARMACK, E.C. 1991. The role of large-scale under-ice topography in separating estuary and ocean on an Arctic shelf. Atmosphere-Ocean 29:37-53.

MACDONALD, R.W., PEARSON, R., SIEBERG, D., McLAUGHLIN, F.A., O’BRIEN, M.C., PATON, D.W., CARMACK, E.C., FORBES, J.R., and BARWELL-CLARKE, J. 1992. NOGAP B.6: Physical and chemical data collected in the Beaufort Sea and Mackenzie River Delta, April-May, 1991. Canadian Data Report of Fisheries and Aquatic Sciences 104. Sidney, British Columbia: Fisheries and Oceans Canada. 155 p.

MACDONALD, R.W., PATON, D.W., CARMACK, E.C., and OMSTEDT, A. 1995. The freshwater budget and under-ice spreading of Mackenzie River water in the Canadian Beaufort Sea based on salinity and ${ }^{18} \mathrm{O} /{ }^{16} \mathrm{O}$ measurements in water and ice. Journal of Geophysical Research 100:895-919.

MACDONALD, R.W., SOLOMON, S.M., CRANSTON, R.E., WELCH, H.E., YUNKER, M.B., and GOBEIL, C. 1998. A sediment and organic carbon budget for the Canadian Beaufort shelf. Marine Geology 144:255-273.

MACDONALD, R.W., CARMACK, E.C., and PATON, D.W. 1999. Using the $\delta^{18} \mathrm{O}$ composition in landfast ice as a record of Arctic estuarine processes. Marine Chemistry 65:3-24.

MACKAY, J.R. 1963. The Mackenzie Delta area, NWT. Memoir 8. Ottawa: Canadian Department of Mines and Technical Surveys, Geographical Branch. 202 p.

McDONALD, M., ARRAGUTAINAQ, L., and NOVALINGA, Z. 1997. Voices from the Bay: Traditional ecological knowledge of the Inuit and Cree in the Hudson Bay bioregion. Ottawa: Canadian Arctic Resources Committee and Sanikiluaq: Environmental Committee of Municipality of Sanikiluaq.

McELDERRY, H. 1986. Areal survey for Pacific herring in Liverpool Bay, N.W.T. Unpubl. manuscript. Available from Fisheries and Oceans Canada, 501 University Avenue, Winnipeg, Manitoba R3T 2N6.

McGHEE, R. 1988. Beluga hunters: An archaeological reconstruction of the history and culture of the Mackenzie Delta Kittegaryumuit, 2nd ed. Social and Economic Studies 13. St. John's, Newfoundland: Memorial University. 124 p.

MELLING, H. 1993. The formation of a haline shelf front in the wintertime in an ice-covered Arctic sea. Continental Shelf Research 13:1123-1147.

MELLING, H., and LEWIS, E.L. 1982. Shelf drainage flows in the Beaufort Sea and their effect on the Arctic Ocean pycnocline. Deep-Sea Research 29:967-985.
MELLING, H., and MOORE, R.M. 1995. Modification of halocline source waters during freezing on the Beaufort Sea shelf: Evidence from oxygen isotopes and dissolved nutrients. Continental Shelf Research 15:89-113.

MORROW, P., and SCHNEIDER, W., eds. 1995. When our words return: Writing, hearing, and remembering oral traditions of Alaska and the Yukon. Logan: Utah State University Press. $244 \mathrm{p}$.

MYERS, R.A., and WORM, B. 2003. Rapid worldwide depletion of predatory fish communities. Nature 423:280-283.

OAKES, J., RIEWE, R., WILDE, K., EDMUNDS, A., and DOBOIS, A. 2003. Native voices in research. Winnipeg: Aboriginal Issues Press, University of Manitoba. 347 p.

PEARSON, R., O'BRIEN, M.C., SIEBERG, D., McLAUGHLIN, F.A., PATON, D.W., TUELE, D., BARWELL-CLARKE, J., CARMACK, E.C., MACDONALD, R.W., and GALBRAITH, M. 1994. NOGAP B.6: Physical and chemical data collected in the Beaufort Sea and Mackenzie River Delta, April-May and September 1992 and ice core data collected in 1991-1992. Canadian Data Report of Hydrography and Ocean Sciences 129. Sidney, British Columbia: Fisheries and Oceans Canada. 198 p.

POPPER, K.R. 1983. Realism and the aim of science. London: Hutchison \& Co. 423 p.

RAYBURN, A. 2001. Naming Canada: Stories about Canadian place names, 2nd ed. Toronto: University of Toronto Press. $360 \mathrm{p}$.

RIEDLINGER, D., and BERKES, F. 2001. Contributions of traditional knowledge to understanding climate change in the Canadian Arctic. Polar Record 37:315-328.

SIGNELL, R., and GEYER, W. 1991. Transient eddy formation around headlands. Journal of Geophysical Research 96(C2):2561-2575.

STROEVE, J., HOLLAND, M.M., MEIER, W., SCAMBOS, T., and SERREZE, M. 2007. Arctic sea ice decline: Faster than forecast. Geophysical Research Letters 34, L09501, doi:10.1029/ 2007 GL029703.

TAYLOR, G.I. 1954. The dispersion of matter in turbulent flow through a pipe. Proceedings of the London Mathematical Society, Series A 223:446-468.

TURNER, N.J. 2005. The Earth's blanket: Traditional teachings for sustainable living. Vancouver: Douglas and McIntyre. $298 \mathrm{p}$.

TURNER, N.J., IGNACE, M.B., and IGNACE, R. 2000. Traditional ecological knowledge and wisdom of aboriginal peoples in British Columbia. Ecological Applications 1:1275-1287.

TURNER, N.J., DAVIDSON-HUNT, I.J., and O'FLAHERTY, M. 2003. Living on the edge: Ecological and cultural edges as sources of diversity for social-ecological resilience. Human Ecology 31:439-461.

USHER, P.J. 2000. Traditional ecological knowledge in environmental assessment and management. Arctic 53(2): $183-193$.

YOUNG, O.R., OSHERENKO, G., EKSTROM, J., CROWDER, L.B., OGDEN, J., WILSON, J.A., DAY, J.C., DOUVERE, F., EHLER, C.N., McLEOD, K.L., HALPERN, B.S., and PEACH, R. 2007. Solving the crisis in ocean governance: Placed-based management of marine ecosystems. Environment 49(4):20-32. 